\title{
8
}
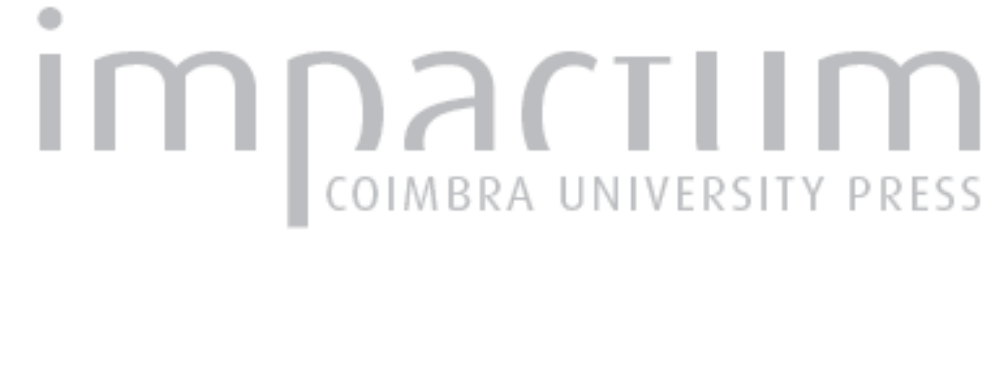

\section{A multiculturalidade na Europa: tendências, reflexões e desafios, a propósito da população escolar de um município da área metropolitana de Lisboa}

\author{
Autor(es): $\quad$ Alcoforado, Luís; Fernandes, João Luís J.; Gama, Rui; Barros, Cristina; \\ Frias, Mafalda; Cordeiro, António M. Rochette
}

Publicado por: Imprensa da Universidade de Coimbra

URL

persistente:

URI:http://hdl.handle.net/10316.2/43680

DOI:

DOI:https://doi.org/10.14195/1647-6336_19_6

Accessed : $\quad$ 26-Apr-2023 01:28:30

A navegação consulta e descarregamento dos títulos inseridos nas Bibliotecas Digitais UC Digitalis, UC Pombalina e UC Impactum, pressupõem a aceitação plena e sem reservas dos Termos e Condições de Uso destas Bibliotecas Digitais, disponíveis em https://digitalis.uc.pt/pt-pt/termos.

Conforme exposto nos referidos Termos e Condições de Uso, o descarregamento de títulos de acesso restrito requer uma licença válida de autorização devendo o utilizador aceder ao(s) documento(s) a partir de um endereço de IP da instituição detentora da supramencionada licença.

Ao utilizador é apenas permitido o descarregamento para uso pessoal, pelo que o emprego do(s) título(s) descarregado(s) para outro fim, designadamente comercial, carece de autorização do respetivo autor ou editor da obra.

Na medida em que todas as obras da UC Digitalis se encontram protegidas pelo Código do Direito de Autor e Direitos Conexos e demais legislação aplicável, toda a cópia, parcial ou total, deste documento, nos casos em que é legalmente admitida, deverá conter ou fazer-se acompanhar por este aviso.

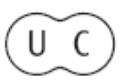


DEBATER

A EUROPA

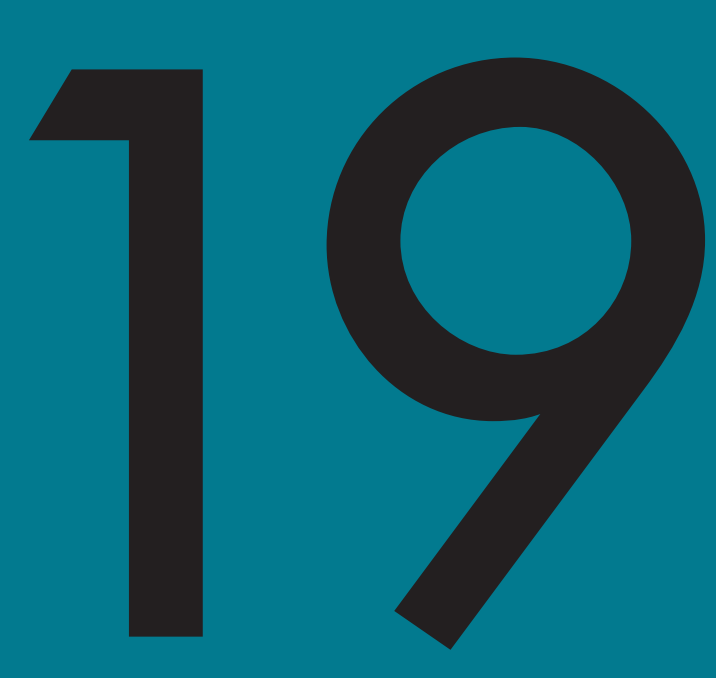

jul-dez 2018

QUE DESAFIOS À CIDADANIA EUROPEIA NO SÉCULO XXI?

WHAT CHALLENGES TO EUROPEAN

CITIZENSHIP IN THE 21ST CENTURY? 


\section{A multiculturalidade na Europa: tendências, reflexões e desafios, a propósito da população escolar de um município da área metropolitana de Lisboa}

Multiculturalism in Europe: trends, reflections and challenges, regarding the school population of a municipality in the Lisbon Metropolitan Area

Luís Alcoforado, $\mathrm{PhD}$

Professor, Faculdade de Psicologia e Ciências da Educação da Universidade de Coimbra, CEIS20 lalcoforado@fpce.uc.pt

João Luís J. Fernandes, PhD Professor, Faculdade de Letras da Universidade de Coimbra, CEIS20 jfernandes@fl.uc.pt Rui Gama, PhD Professor, Faculdade de Letras da Universidade de Coimbra, CEGOT rgama@fl.uc.pt

Cristina Barros, MSc Bolseira de Investigação, Faculdade de Letras da Universidade de Coimbra cbarros@fl.uc.pt

Mafalda Frias, MSc Bolseira de Investigação FCT (SFRH/BD/131426/2017) Faculdade de Psicologia e Ciências da Educação da Universidade de Coimbra friasmafalda@gmail.com

António M. Rochette Cordeiro, PhD Professor, Faculdade de Letras da Universidade de Coimbra, CEIS20 rochettecordeiro@fl.uc.pt 


\title{
Resumo
}

As dinâmicas populacionais da Europa revelam-se em diferentes escalas. O município de Sintra tem aspetos particulares, mas reflete dinâmicas da área metropolitana de Lisboa, do país e do continente europeu. A fixação de populações diversificadas e estruturas demográficas mais jovens, assim como o incremento das distâncias culturais, constituem um desafio a enfrentar pelo sistema escolar. Partindo da caraterização das dinâmicas migratórias na Europa e em Portugal, neste trabalho apresentam-se dados exploratórios sobre a heterogeneidade étnica e cultural, as dinâmicas socioespaciais e as políticas locais de integração das diferentes comunidades de Sintra, com particular ênfase na área educativa.

Palavras chave: Multiculturalidade, Interculturalidade, Projeto Educativo Local.

\begin{abstract}
Europe's population dynamics are represented at various scales. While the municipality of Sintra has specific features, it nevertheless reflects the dynamics of the Lisbon metropolitan area, of the country and of the European continent. The settlement of diverse populations and younger populations, as well as the increase of cultural gaps pose a challenge to the school system. This paper is based on the characterisation of the migratory dynamics in Europe and in Portugal, presenting the exploratory data on the ethnic and cultural diversity, the social and spacial dynamics, and local policies on the integration of the various communities found in Sintra, with aprticular emphasis on the educational area.
\end{abstract}

Keywords: Multiculturalism, Interculturality, Local Educational Project.

\section{Introdução}

A atualidade, no contexto de um mundo mais interdependente, requer ampla discussão em torno das questões da mobilidade espacial das populações, da diversidade cultural, das relações interculturais e da coexistência de comunidades com diferentes identidades, tradições, religiões, competências e saberes.

A diversidade cultural não é uma novidade na Europa. No entanto, traduzindo-se em cartografias de multiculturalidade ou em dinâmicas de interculturalidade, esta é uma realidade incontornável das sociedades contemporâneas, contribuindo para o desenvolvimento de novas formas de relações sociais, de integração de comunidades culturalmente diferentes, de partilha de saberes, não raras vezes acompanhadas pela emergência de conflitos e problemas de comunicação, conduzindo a novas formas de exclusão e discriminação.

Ainda que nem sempre os Estados consigam regular estes fluxos espaciais, a eles compete a salvaguarda da igualdade de todos os cidadãos estrangeiros, que devem 
usufruir das mesmas condições que os cidadãos nacionais. O campo da Educação é provavelmente um dos mais importantes barómetros da eficácia ou ineficácia das políticas de acolhimento. Uma eficaz integração e o sucesso educativo dos alunos originários de outras culturas e/ou descendentes de imigrantes afigura-se como um importante indicador de coesão social (Ramos, 2007) e um relevante fator de desenvolvimento dos próprios territórios.

Neste contexto, os Estados devem assegurar que todas as crianças e jovens tenham acesso à educação em igualdade de circunstâncias, justificando-se o reforço de medidas e programas de apoio que garantam condições de igualdade para todas as crianças e jovens.

Para Touraine (2005), na atualidade estamos perante a necessidade de responder a um conjunto progressivamente mais alargado de problemas de natureza cultural, pelo que a vocação da escola não se deve orientar apenas para a instrução, mas deverá colocar, também, como um dos seus objetivos centrais, o encorajamento da convivência com a diversidade cultural (Torraine, 1999). No entanto, é incontornável que a vocação da escola não se deve orientar apenas para a instrução. Ao mesmo tempo, terá que colocar, como um dos seus objetivos centrais, o encorajamento da convivência com a diversidade cultural (Torraine, 1999). Através de atividades pelas quais se forma e se afirma a personalidade dos alunos, a escola deve ser um espaço e um tempo que predisponham o envolvimento dos estudantes em práticas aprofundadas de diálogo intercultural, entendido como o conjunto de partilhas racionais e equilibradas, entre parceiros iguais, que se respeitam mutuamente e debatem, ou discutem, de modo construtivo, partilhando as suas experiências, aprendendo com ou outros (e a partir da experiência dos outros), num processo de enriquecimento mútuo (Lahire, 2011). Voltando aos contributos de Torraine (1999), a escola deve assumir-se, por isso mesmo, como um lugar privilegiado de encontros interculturais, tendo um papel preponderante na promoção da autoestima e confiança, na promoção das relações sem preconceitos e discriminações, criando oportunidades para que as crianças das minorias consigam desenvolver-se com conhecimentos suficientes, atitudes e competências necessárias à aquisição de estudos académicos, emprego e participação cidadã, em completa igualdade de circunstâncias entre todos os cidadãos de uma mesma comunidade e sociedade.

Neste sentido, as políticas públicas necessitam, cada vez mais, de assumir a Escola como um importante elo de ligação e diálogo nas sociedades multiculturais, promovendo os meios que possibilitem a adequação das experiências educativas à realidade social e à articulação com as famílias e a comunidade em que está inserida (Ramos, 2007), vendo-a como espaço de encontro das diferenças, de convivência entre diferentes culturas e aprendizagens, de educação e desenvolvimento integral de todas as crianças e jovens, quer sejam migrantes ou autóctones. Como salientou Giroux (1983: 293) "as escolas não mudam a sociedade, mas podem criar-se nelas bolsas de resis- 
tência que proporcionem modelos pedagógicos para novas formas de aprendizagem e de relações sociais, formas que possam ser utilizadas noutras esferas mais diretamente implicadas na luta por uma nova ética e uma nova visão de justiça social".

Enquanto país aberto e dependente do exterior, Portugal sempre se caraterizou pela mobilidade espacial da população que atravessou a fronteira política em ambos os sentidos. Na atualidade, apesar dos efeitos estruturais da emigração (segundo o Observatório da Emigração, são mais de 2 milhões os portugueses na diáspora), nas últimas décadas diversificaram-se, e ganharam centralidade, os territórios de imigração no espaço geográfico português. Em 2016 a população de origem estrangeira totalizava 407504 indivíduos (3,8\% da população residente segundo dados do INE), sendo que com estatuto legal de residência existiam 392969 indivíduos, provenientes de 185 países diferentes (SEF, 2016). Nesse ano, os cidadãos brasileiros assumiam-se como os mais representativos (20,2\%), seguindo-se as comunidades de Cabo Verde (9,2\%), da Ucrânia $(8,8 \%)$ e da Roménia (7,7\%). Desta heterogeneidade cultural e linguística, com proveniências muito diferenciadas, resulta uma sociedade na qual os diferentes setores sociais, em particular a instância educativa e a escola, se confrontam com comunidades escolares que são mosaicos linguísticos e culturais muito complexos (Ramos, 2007). Este quadro coloca novas exigências na adoção de estratégias e políticas eficazes para responder a este desafio.

O município de Sintra é um exemplo paradigmático desta realidade, uma vez que muito do seu crescimento populacional se deveu à chegada e fixação de população imigrante. No contexto nacional, Sintra concentra o maior número de estrangeiros (32709, correspondendo a 8,7\% dos residentes), oriundos de mais de 130 nacionalidades diferentes de acordo com os dados do INE. A expressividade da população jovem estrangeira é evidente, contabilizando-se 7289 crianças e jovens até aos 19 anos no ano de 2011 , correspondendo a $32,4 \%$ da população estrangeira e a $8,2 \%$ do total de crianças e jovens com essas idades. De igual modo é reforçada a importância dos descendentes de imigrantes, contabilizando-se, no período entre 2002 e 2016, cerca de 14894 crianças de mães estrangeiras, o que representa cerca de 22,4\% dos nascimentos em igual período no concelho. No ano mais recente (2016), nasceram 864 crianças de mães estrangeiras, correspondendo a $22,6 \%$ do total dos nascimentos, destacando-se uma vez mais a importância da população estrangeira para o rejuvenescimento populacional'.

Partindo de um quadro de caraterização global das dinâmicas migratórias na Europa e em Portugal, e focando-nos em particular no concelho de Sintra, apresentamos, neste trabalho, dados exploratórios sobre a crescente heterogeneidade étnico-cultural,

1 Deve ser referido que no presente caso são apenas apresentados dados relativos às crianças cujas mães não apresentam nacionalidade portuguesa, pelo que o valor dos filhos de descendentes apresenta-se com toda a certeza muito mais significativo. 
as dinâmicas socio espaciais e as políticas locais de integração das diferentes comunidades, com particular enfase na área educativa. Pretendemos, a partir dessas constatações, refletir sobre a oportunidade de acesso e sucesso escolares das crianças e jovens imigrantes, constatando que os estudantes imigrantes ou descendentes de imigrantes sentem, demasiadas vezes, maiores dificuldades do que os seus pares endógenos no desempenho escolar, no acesso à educação pré-escolar, e na progressão normal através dos vários ciclos educativos (Seabra et al, 2011).

\section{Multiculturalidade, Interculturalidade e Comunidade}

A mobilidade espacial da população e os efeitos que daqui resultam na Geografia Cultural e até na Geografia Política dos territórios não é uma novidade (Brah, 1996). Pelo contrário, são utópicos os sistemas estáveis e imperturbados por fluxos que acabam por criar novas realidades e implicar desafios inovadores em múltiplas dimensões, como a educação. Se a deslocação de populações é uma constante ao longo da História da humanidade e, muito em particular, da própria Europa, já o modo como se territorializam estes recém-chegados varia consoante a distância que se estabelece, no território de chegada, entre as culturas dominantes e as culturas minoritárias (Hemmasi \& Downes, 2013). Significa isto que há uma diferença entre as minorias que se confinam em territorialidades autocentradas definidas por limites, quantas vezes até espaciais, impermeáveis ao contacto, e aquelas que, pelo contrário, se agregam estabelecendo pontes de contacto com o exterior. No primeiro caso, estaremos a referir-nos ao domínio da multiculturalidade, mais comum na Europa. No segundo, aponta-se para processos de interculturalidade, um nível de trocas e de intermediações de concretização mais difícil.

Estas diferenças têm servido de base a um longo debate teórico que atravessa domínios como o das territorialidades e das identidades, ambos de forma direta implicados na educação.

As culturas minoritárias confinadas concretizam aquilo que autores como Sen (2007) e Maalouf(1999) associam às identidades unipolares de pertença única. Nesta ideia de comunidade, e sigam-se aqui as ideias de Granovetter (1973), privilegiam-se os laços fortes, as filiações de pertença, os laços históricos e sanguíneos. Nestes territórios monoculturais, privilegiam-se os dogmas e valorizam-se os valores do passado que mantêm o grupo unido perante as ameaças provenientes do exterior. Daqui resultaram conceções políticas de exclusão e confronto entre grupos e de choques de civilizações perante fronteiras culturais aqui consideradas como linhas de tensão (Huntington, 1993 e 1999).

Este mosaico cultural é, mais uma vez para Sen (2007) e Maalouf (1999), um potencial de instabilidade e violência, um fator de reforço do desconhecimento e do estereótipo daquele que, do outro lado do muro, não pertence ao grupo. Para Rogério Haesbaert (2004), 
as identidades de múltipla pertença e as multiterritorialidades de inclusão implicam cidadãos filiados aos seus grupos de origem mas abertos, num sistema mais aberto de trocas e partilhas, à construção de identidades topoligâmicas e compósitas, utilizando aqui uma expressão de Sen (2007).

Estas são questões que atravessam múltiplos domínios da sociedade, a começar pela família e pela religião, mas também, de forma mais ampla, pela educação. A escola, enquanto instituição mas também como território de práticas sociais e culturais, refletirá este dualismo. Por um lado, poderemos estar perante práticas que reforcem a dimensão monocultural do grupo (muitas escolas religiosas, em diferentes países do mundo, seguem este modelo). Por outro, podemos estar perante instituições que, indiferentes às especificidades destes grupos culturais minoritários, lhes imponham um caminho de uniformização e diluição que também comporta riscos.

Por outro lado, enquanto janelas de um determinado quadro social, estas instituições poderão espelhar as heterogeneidades sociais e as diferenças de poder económico e político que, estando a montante, se projetam no (in)sucesso dos estudantes com origem em grupos culturais minoritários.

\section{A diversidade cultural da Europa}

A integração e inclusão de migrantes é uma questão central na agenda europeia. De facto, existe um reconhecimento generalizado de que as migrações são um fenómeno atual e que a integração eficaz dos migrantes é um dos principais desafios da Europa, tendo em conta a dimensão avassaladora do fluxo migratório previsto para as próximas décadas (Boussemart \& Godet, 2018).

A Europa de hoje, e do passado, reflete-se num território de grande confluência cultural. Comprova-o o facto de o atlas linguístico europeu revelar um continente com uma imensa diversidade e complexidade. Segundo Gómez (2011), é possível identificar mais de 450 territórios linguísticos (entre línguas nacionais e dialetos), bem como uma grande diversidade antropomórfica e uma multitude de sensibilidades musicais, estéticas, gastronómicas, literárias, filosóficas. Esta diversidade é visível não apenas comparando unidades políticas, mas sobretudo no interior destas, revelando micro, meso e macrogeografias linguísticas, de tradições, costumes e práticas (Machado, 2005). Este mosaico de diversidade cultural decorre do processo de convergência entre grupos étnicos e culturais, ocorrida ao longo do tempo, sem que se tenha atingido um estado de aproximação. Pelo contrário, a própria geografia europeia foi proporcionando processos de insularização e acantonamento cultural, com as quais a União Europeia deve hoje lidar.

De facto, os movimentos migratórios foram desde sempre uma realidade partilhada pelos países europeus, tendo sido determinados por causas e fatores como as guerras, 
a instabilidade política e económica, a falta de oportunidades de trabalho nos países de origem e os episódios associados a catástrofes naturais.

Os primeiros movimentos maciços de população europeia datam da Revolução Industrial, das melhorias das condições de vida, dos progressos na medicina e nas comunicações vividos por uma população em expansão demográfica, em finais do século XVIII e inícios do século XIX. Neste período foram intensos os movimentos migratórios para fora da Europa, aumentando os contingentes populacionais sobretudo na América do Norte.

No entanto, o século $\mathrm{XX}$ foi o que conheceu as maiores vagas migratórias no continente europeu. Se após a Primeira Guerra Mundial, como resultado de expulsões e perseguições políticas, étnicas e ideológicas, saíram grandes contingentes populacionais, após a Segunda Guerra Mundial, inverte-se esta situação, deixando a Europa de ser um continente de emigração para passar a receber milhares de imigrantes, encarados como essenciais para o processo de reconstrução europeia. A este movimento deveu-se a eficácia do Plano Marshall (1947) e o desenvolvimento e aprofundamento de políticas de integração europeia, que anularam barreiras comerciais e deram origem a um elevado crescimento económico em poucos anos em alguns países europeus.

Mais tarde, e sobretudo a partir da década de 60 intensificaram-se os fluxos migratórios intracontinentais, principalmente pelos migrantes de países mais pobres, como Portugal, Grécia, Espanha, Irlanda, para países com maior prosperidade económica, como França e Alemanha, mas também a Suíça e Luxemburgo. Paralelamente, aumentaram os fluxos intercontinentais, como consequência do processo de descolonização, trazendo mão-de-obra mais barata proveniente das antigas colónias.

A crise petrolífera de 1973, e a recessão económica decorrente, ditaram a aplicação de políticas restritivas de imigração, marcando o início de uma nova fase nos processos migratórios europeus (Baganha \& Góis, 1998).

Em plena recessão económica, os anos 80 são marcados pela perceção, no seio da comunidade europeia, da formação de comunidades imigrantes territorialmente concentradas e com claros sintomas de exclusão sociocultural, agravados pelas condições de trabalho, habitação e remuneração muito abaixo das respetivas médias nacionais (Baganha \& Góis, 1998). Decorrente desta situação, e desde meados dos anos 70, a intervenção política europeia pautou-se pelo desenvolvimento de medidas de integração das comunidades anteriormente formadas e pelo desincentivo à vinda de mais trabalhadores imigrantes.

Com o desenvolvimento e alargamento da União Europeia e com a entrada em vigor do Acordo de Schengen (1985), as fronteiras foram reabertas de forma controlada e a mobilidade restabeleceu-se. Durante os anos 80 e 90, uma grande parte da procura nos territórios europeus ocidentais diziam respeito a pedidos de asilo por parte da população dos países comunistas da Europa de Leste. A desintegração do antigo bloco soviético estruturou fluxos de sentido leste-oeste, que acabaram por marcar a demografia de parte dos países ocidentais, como Portugal. 
Mais tarde, e fundamentalmente a partir do ano 2000, a Europa converte-se num importante espaço de prosperidade, atraindo população sobretudo de África, Ásia e América Latina, em busca de melhores condições políticas, sociais e económicas. $\mathrm{Na}$ atualidade, o aumento das tensões, instabilidade política e guerras sentidas no Norte de África e no Médio Oriente trouxe um inevitável fluxo maciço de cidadãos oriundos de áreas como a África Subsaariana, Iraque, Síria, Líbia, Turquia, Eritreia ou Afeganistão, em busca de proteção por parte da União Europeia. No ano de 2015, cerca de 1,25 milhão de pessoas oriundas destes países apresentaram pedidos de asilo. De acordo com a Organização Internacional para as Migrações, no ano de 2017 chegaram à Europa, por mar, cerca de 60 mil imigrantes e refugiados, um pouco menos do que no ano de 2016 (361 mil pessoas).

Neste contexto, pode-se concluir que o crescimento demográfico da Europa se fez em larga medida a partir das deslocações massivas de populações intra e extraeuropeias. Esta dimensão multicultural europeia pode ser visível na média de cerca de $8 \%$ de residentes não nacionais nos países da União Europeia no ano de 2016. Em alguns países, a percentagem é superior, como é o caso do Luxemburgo (46,7\%), Chipre (16,5\%), Estónia (15\%), Letónia (14,7\%), Áustria (14,4\%), Irlanda (12,4\%), Bélgica (11,7\%) e Alemanha (10,5\%). À exceção da Lituânia e da Letónia, todos os outros países registaram um acréscimo no peso da população estrangeira entre 2001 e 2016 (Figura 1).

Em termos absolutos ganham destaque países como a Alemanha, Reino Unido, França, Espanha e Itália, uma vez que apresentam maiores quantitativos de imigrantes no ano de 2015. O saldo entre as entradas e saídas, posiciona países como a Roménia, Grécia, Polónia, Lituânia, Croácia, Letónia e Portugal com maiores níveis de repulsão, dado o desequilíbrio entre os que saem e os que entram no país (Quadro 1).

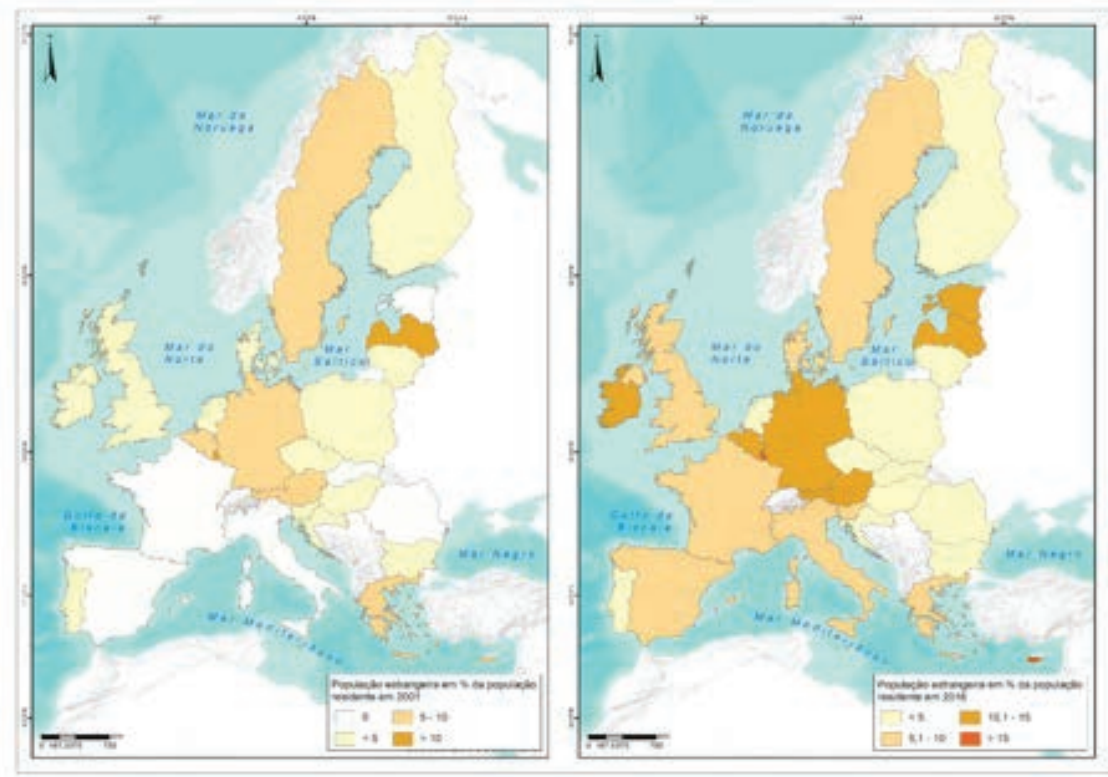

Fonte: Questionário Conjunto sobre Dados Anuais de Migrações. Eurostat | NU | OIT | Entidades Nacionais.

Figura 1. Proporção da população residente estrangeira nos países da UE (28) em 2001 e 2016. 


\begin{tabular}{|c|c|c|c|c|c|c|}
\hline \multirow{2}{*}{ País es } & \multicolumn{2}{|c|}{2001} & \multicolumn{2}{|c|}{2011} & \multicolumn{2}{|c|}{2015} \\
\hline & Imxigraçăo & Emigraçăo & Imigração & Emigração & Innigraçăo & Frnigração \\
\hline Alemanha & 879217 & 606494 & 489422 & 249045 & 1543848 & 347162 \\
\hline Áustria & 89928 & 72654 & 82230 & $\$ 1197$ & 166323 & 56689 \\
\hline Bélgica & 110410 & 75261 & 147377 & 84148 & 146626 & 89794 \\
\hline Bulgária & 0 & 0 & 0 & 0 & 25223 & 29470 \\
\hline Chipre & 17485 & 0 & 23037 & 4895 & 15183 & 17183 \\
\hline Croácia & 24415 & 7488 & 8534 & 12699 & 11706 & 29651 \\
\hline Dinamarea & 55984 & 43980 & 52833 & 41593 & 78492 & 44625 \\
\hline Eslováquia & 2023 & 1011 & 4829 & 1863 & 6997 & 3870 \\
\hline Eslovénia & 7803 & 4811 & 14083 & 12024 & 15420 & 14913 \\
\hline Espanha & 414772 & 0 & 371331 & 409034 & 342114 & 343875 \\
\hline Estónia & 241 & 2175 & 3709 & 6214 & 15413 & 13003 \\
\hline Finlindia & 18955 & 13153 & 29481 & 12660 & 28746 & 16305 \\
\hline França & 0 & 0 & 319816 & 291594 & 363869 & 297969 \\
\hline Grécia & 98471 & 45909 & 60089 & 92404 & 64446 & 109351 \\
\hline Hungria & 22079 & 2591 & 28018 & 15100 & 58344 & 43225 \\
\hline Irlanda & 64925 & 25750 & 53224 & 87053 & 76888 & 77128 \\
\hline Itália & 208252 & 56077 & 385793 & 82461 & 280078 & 146955 \\
\hline Letónia & 5376 & 24539 & 10234 & 30311 & 9479 & 20119 \\
\hline Lituănia & 4694 & 27841 & 15685 & 53863 & 22130 & 44533 \\
\hline Luxemburgo & 12135 & 8824 & 20268 & 9264 & 23803 & 12644 \\
\hline Malta & 0 & 0 & 5465 & 3806 & 12831 & 8655 \\
\hline Paises Baixos & 133404 & 63318 & 130118 & 104201 & 166872 & 112330 \\
\hline Poknia & 6625 & 23368 & 157059 & 265798 & 218147 & 258837 \\
\hline Portugal & 61609 & 5396 & 19667 & 43998 & 29896 & 40377 \\
\hline Reino Unido & 372206 & 251369 & 566044 & 350703 & 631452 & 299183 \\
\hline República Checa & 12918 & 21469 & 27114 & 55910 & 29602 & 25684 \\
\hline Romónia & 0 & 0 & 147685 & 195551 & 132795 & 194718 \\
\hline Suécia & 60795 & 32141 & 96467 & 51179 & 134240 & 55830 \\
\hline Total & 2684722 & 1415619 & 3269612 & 2618568 & 4650963 & 2754078 \\
\hline
\end{tabular}

Fonte: Questionário Conjunto sobre Dados Anuais de Migrações. Eurostat | NU | OIT | Entidades Nacionais.

Quadro 1. Imigração e Emigração nos países da UE, entre 2001 e 2015.

Num momento em que a Europa tem vindo a perder a sua capacidade de renovação de gerações, e ao mesmo tempo que tem caminhado para um progressivo envelhecimento populacional, a imigração deverá ser vista como um imperativo para o crescimento demográfico e económico (Boussemart \& Godet, 2018). Os estados-membros da União Europeia reconhecem que a imigração continuará a ser uma realidade, pelo que os esforços deverão ser no sentido de se assegurar a coesão social, garantindo a integração dos imigrantes nos mercados de trabalho europeus, uma vez que o seu trabalho e as suas competências continuarão a ser essenciais para a prosperidade da Europa (Machado, 2005).

As migrações podem proporcionar vantagens importantes. São já várias as gerações de migrantes de todo o mundo que têm vindo a instalar-se e a prosperar na Europa, contribuindo muito positivamente nas esferas económica e cultural.

\subsection{A crescente heterogeneidade étnico-cultural em Portugal}

Apesar de nem sempre devidamente estudados, os estrangeiros em território português sempre foram atores relevantes. Muitas referências envolvem os refugiados espanhóis ou 
imigrantes com uma longa história de integração e dinamização de sectores específicos da economia portuguesa, como por exemplo, ligados ao vinho do Porto (Pires, 2003; Castro, 2008).

Durante a década de (19)70, os imigrantes que chegavam a Portugal eram fundamentalmente oriundos do continente africano, os quais mantinham ligações familiares, sociais, identitárias entre os dois territórios. Paralelamente chegavam indivíduos oriundos do Reino Unido e da Alemanha ligados às atividades da indústria e do turismo. Na década seguinte, Ferreira et al (2000) referem-se ao desencadeamento de movimentos migratórios clandestinos oriundos de países em vias de desenvolvimento, muitos dos quais escolheram Portugal, e outros países do sul, para a inserção de uma mão-de-obra pouco especializada.

A partir dos anos 90 dá-se um aumento exponencial de imigrantes, sobretudo de países africanos lusófonos, mas também brasileiros e de indivíduos oriundos do leste europeu. Em 2001 estima-se que viveriam em Portugal cerca de 223997 indivíduos com estatuto legal de residência segundo os dados do Pordata. Após este ano, e até 2009, a tendência expressa-se num aumento muito expressivo, sendo que nesse ano existiriam 451742 estrangeiros a residir em Portugal. A partir de 2010, inverte-se a tendência, observando-se um declínio no número de estrangeiros, para um total de 392969 em 2016. Ainda assim, entre 2001 e 2016 o aumento foi superior a 75\%, correspondendo a mais 168972 imigrantes a residir legalmente em Portugal (Figura 2).

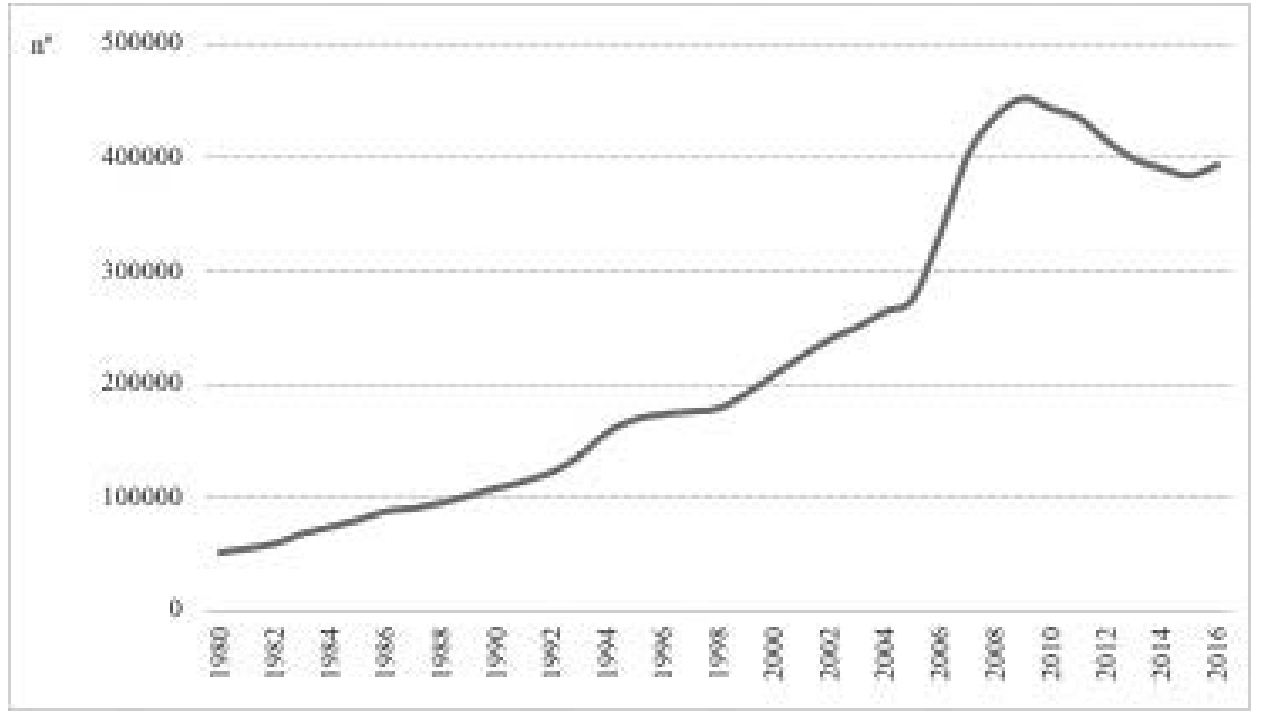

Fonte: Pordata.

Figura 2. Evolução da população estrangeira com estatuto legal de residente em Portugal, entre 1980 e 2016.

No que diz respeito à proveniência desta população estrangeira em Portugal, em 2011 predominavam os Europeus (36,4\%), seguindo-se os Americanos (30,8\%), os Africanos $(26,8 \%)$ e os Asiáticos (5,9\%) (Figura 3). Em termos do mercado de trabalho, é possível afirmar que a população imigrante ocupa duas franjas extremas no país. Por um lado, 
inclina-se para a parte mais alta da escala laboral (alguns europeus e brasileiros), por outro para a mais baixa (africanos e europeus de leste) (Baganha, 1999; Castro, 2008).

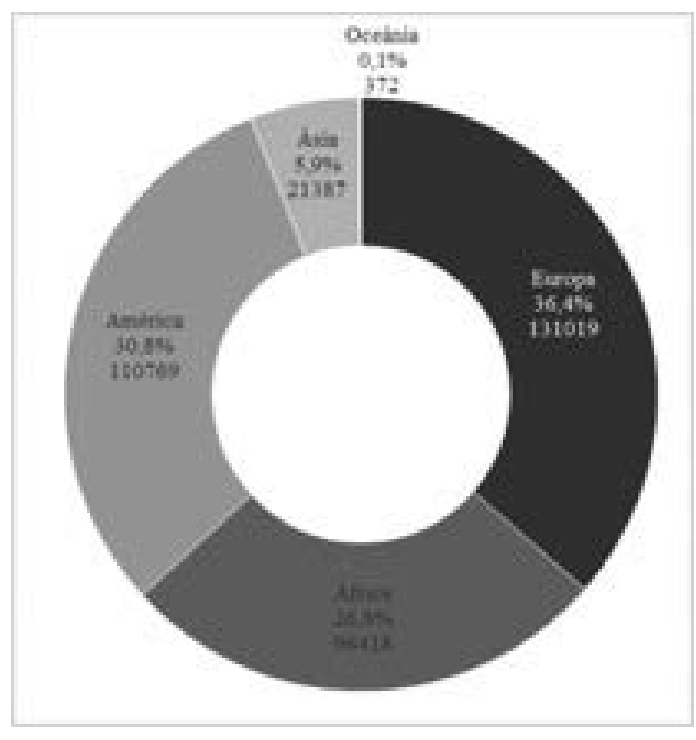

Fonte: INE.

Figura 3. População residente estrangeira em Portugal, por continente de origem, em 2011.

Numa outra leitura, torna-se interessante analisar os padrões de fixação da população estrangeira. As áreas metropolitanas de Lisboa e do Porto e a faixa litoral, com uma grande incidência na região algarvia, parecem ser os espaços de eleição para a fixação destes fluxos migratórios. Tratam-se de áreas com maior prosperidade económica, onde a quantidade e diversidade do mercado de trabalho é maior e por consequência, oferecem um maior grau de atratividade.

Com uma maior incidência de população estrangeira no total da população residente no ano de 2016 e de acordo com os dados disponíveis no Pordata, destacam-se os concelhos de Albufeira (24,6\%), Vila do Bispo (21,7\%), Lagos (20,9\%), Aljezur (18,5\%), Loulé $(17,9 \%)$ e Odemira (16,9\%). Esta expressão está relacionada fundamentalmente pela procura por parte de cidadãos europeus, das condições de vida que Portugal oferece para gozar a reforma. Para Fonseca (2002), trata-se de um grupo apelidado de Sun-Seekers, cuja migração está relacionada com a procura de amenidades climáticas para aproveitar uma fase de maior descontração nas suas vidas.

As motivações relacionadas com a procura de emprego são visíveis em territórios de maior dimensão e maior oferta de emprego, como é o caso de Lisboa $(10,6 \%)$, Cascais (9,8\%), Amadora (9,1\%), Odivelas (7,8\%), Sintra (7,7\%) e Sines (6\%).

Uma leitura à evolução registada entre 2001 e 2016 deixa claro que a esmagadora maioria dos concelhos apresentou um reforço no peso da população estrangeira (Figura 4). Os concelhos algarvios (Albufeira, Odemira, Vila do Bispo, Lagos, Tavira, Loulé, entre outros) foram os que registaram um aumento da importância dos estrangeiros na sua população. 


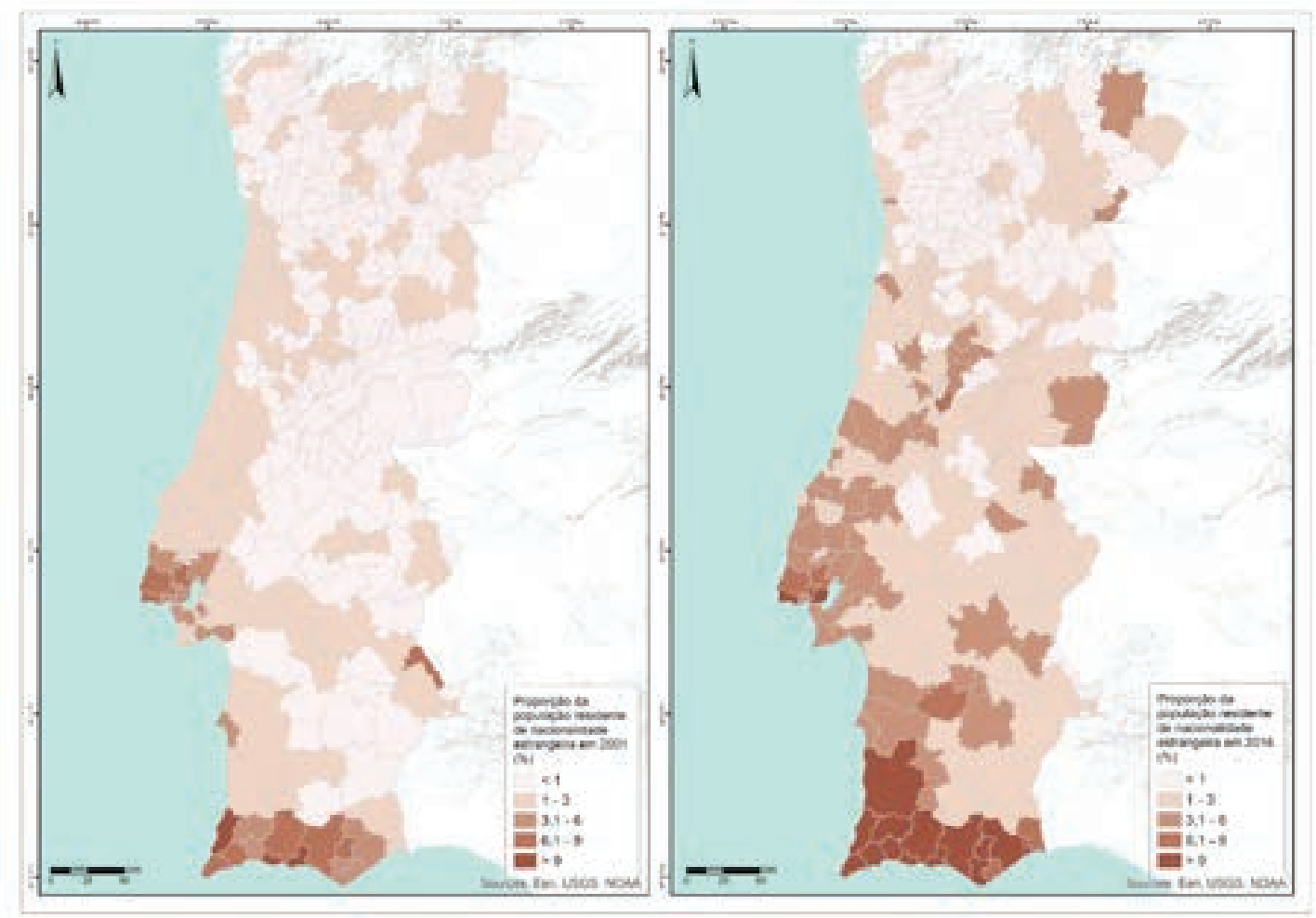

Fonte: Pordata.

Figura 4. Proporção da população residente de nacionalidade estrangeira em 2001 e 2016.

Tentar prever as dinâmicas e dimensões dos fluxos migratórios nos próximos anos torna-se um exercício de grande complexidade dada a natureza imprevisível neste tipo de fenómenos.

Como certo é que, associado aos problemas demográficos com que Portugal se depara (baixas taxas de fecundidade e de natalidade, decréscimo e envelhecimento populacional), o contributo da imigração deve ser analisado como algo muito positivo, principalmente tendo em consideração que a média de idades dos imigrantes é bastante inferior à média de idades da população autóctone, podendo, neste contexto, atenuar em parte o envelhecimento populacional. Para além deste efeito direto na dinâmica demográfica, a população imigrante também gera descendentes, contribuindo para o aumento de novos nados-vivos, frequentemente em maior número, quando comparados com a população feminina local (Peixoto et al, 2017).

Sendo certo que a imigração não se apresenta como nenhuma panaceia para resolver os problemas demográficos com que a Europa, e no caso particular, Portugal, se deparam, os fluxos migratórios são uma variável muito relevante e incontornável para se compreender os fenómenos populacionais da atualidade.

Portugal, tendo sido um forte destino de migrantes nas últimas décadas, confronta-se com relevantes desafios a que terá de dar resposta, como é o caso da luta contra a imigração clandestina e a promoção de modelos adequados de integração, com pleno respeito pelo valor da diversidade, entre outros (Rosa et al, 2003). 


\section{O município de Sintra como território multicultural}

\subsection{Caraterização global}

Tal como foi analisado, o reforço da migração em Portugal fez-se sobretudo para as grandes cidades, uma vez que estas possuíam mercados de trabalho mais amplos e diversificados, oferecendo maiores oportunidades para aqueles que procuravam uma vida melhor (Malheiros, 1996 e 1998).

Assim, a Área Metropolitana de Lisboa concentrava, em 2011, mais de metade dos estrangeiros que residiam em Portugal Continental (53\%, correspondendo a 188391 indivíduos). O concelho de Sintra, em particular, tem-se caraterizado nas últimas décadas por um elevado crescimento populacional, sendo que grande parte se deveu fundamentalmente à população imigrante. De facto, o concelho de Sintra é, no contexto nacional, o município que concentra o maior número de estrangeiros (32709), seguindo-se os municípios de Lisboa (31833) e da Amadora (17853)². Deve ainda ser valorizada a presença de residentes com mais de uma nacionalidade (na sua esmagadora maioria são indivíduos com nacionalidade portuguesa e uma outra nacionalidade), que embora não sejam considerados imigrantes, não deixam de ter uma forte ligação com o seu país de origem. No caso de Sintra, em 2011 existiam 14843 indivíduos enquadrados nesta categoria, correspondendo a 3,93\% da população total.

Em 2011, os estrangeiros legais em Sintra correspondiam a 17,4\% do total de estrangeiros na área metropolitana e a 9,3\% dos estrangeiros no Continente, e representavam $8,7 \%$ do total de habitantes do concelho.

A grande maioria dos imigrantes do concelho (64,10\%, correspondendo a 20967 indivíduos) estavam inseridos numa faixa etária entre os 25 e os 64 anos, encontrando-se, por isso, em idade ativa. Deduz-se, assim, que os fatores de ordem económica continuam a prevalecer na decisão de imigração. O número de crianças e jovens residentes em Sintra apresenta também valores significativos. Em 2011 existiam 7289 crianças e jovens até aos 19 anos, pertencentes a famílias de emigrantes, correspondendo a $32,44 \%$ do total da população estrangeira e a $8,19 \%$ do total de crianças e jovens com estas idades residentes no concelho.

Em termos das habilitações cerca de $46,9 \%$ dos residentes estrangeiros apresentavam apenas o ensino básico concluído, seguindo-se os detentores do ensino secundário (31,69\%), com o ensino superior (10,88\%) e, por fim, cerca de $8,18 \%$ não revelavam qualquer nível de escolaridade atingido. Em termos relativos, os indivíduos provenientes dos continentes africano e asiático são os detentores de habilitações mais débeis, ao passo que os europeus

2 Importa salientar que os dados apresentados são referentes ao ano de 2011, coincidindo com o momento máximo de crise económica e financeira enfrentada por Portugal, pelo que na atualidade, estes valores poderão estar muito alterados. 
e americanos apresentam um perfil de habilitações mais favorável.

A diversidade étnica de Sintra é considerada uma valiosa potencialidade deste território, contribuindo para este facto a existência, em 2011, de mais de 130 nacionalidades diferentes.

No período anterior ao ano 2001 eram os naturais de Angola e Cabo Verde que dominavam a imigração. Estas duas nacionalidades também se destacaram nos anos seguintes, mas invertendo-se as posições. De acordo com os últimos censos, sobressaem os oriundos do Brasil (8056, correspondendo a 24,63\%), Cabo Verde (6921, correspondendo a 21,16\%), Angola (5092, correspondendo a 15,57\%) e Guiné-Bissau (4081, correspondendo a $12,48 \%$ ). Estas caraterizavam-se por serem comunidades jovens, com níveis reduzidos de qualificação e que laboravam em atividades pouco qualificadas em setores como a construção civil, serviços domésticos ou restauração (Horta, 2011). Estas comunidades, em larga medida em consequência dos seus baixos recursos económicos, estão sobre representadas em territórios mais marginalizados.

Porém, e de acordo com Horta (2011), o território de Sintra tem alguma tradição em acolher elites estrangeiras, fazendo com que exista uma certa dicotomia da população estrangeira residente. Por um lado, encontram-se grupos pertencentes a classes sociais privilegiadas, por outro, encontram-se migrantes laborais, nomeadamente dos PALOP ou de países da Europa de Leste.

O fenómeno imigratório observado no país e que, no caso de Sintra, assume contornos particularmente evidentes, deverá ser enquadrado no âmbito das razões que estiveram na base da escolha deste território para viver. Desde logo, a proximidade de familiares e amigos, mostrando que a existência de redes de filiação e consanguinidade é importante, tanto para a decisão de migrar, como para a escolha do território de fixação. Paralelamente, devem ser sublinhados os preços mais baixos da habitação (em comparação sobretudo com o concelho de Lisboa) e a proximidade de pessoas com a mesma nacionalidade. Neste contexto, como é caraterístico nas diásporas, é reconhecida a importância da manutenção de laços com o país de origem, traduzindo-se na reprodução de tradições e práticas culturais de caráter simbólico e material no país de acolhimento. Exemplo disso é a manutenção de hábitos gastronómicos tradicionais, a compra de bens do país de origem ou o interesse pela música da comunidade étnica.

O padrão de localização residencial da população estrangeira evidencia uma maior prevalência no setor sudeste deste território, tratando-se de um setor com maior disponibilidade de espaço de construção, habitação mais barata e uma maior proximidade a Lisboa, tirando partido do efeito positivo da linha ferroviária de Sintra (Figura 5). Em termos absolutos, e com maiores quantitativos, destaca-se a freguesia de Algueirão-Mem Martins (5781 indivíduos), a união das freguesias de Massamá e Monte Abraão (4576) e a união das freguesias de Agualva e Mira-Sintra (4484). Nestes territórios observava-se uma maior importância dos indivíduos oriundos do continente africano, nomeadamente 
dos PALOP. Por outro lado, as freguesias da parte sudoeste e norte de Sintra apresentavam uma evidente sobrevalorização dos nacionais dos países europeus e do continente americano, o que indicia que as populações estrangeiras com maiores níveis de qualificação e rendimentos mais elevados se fixaram nos setores com maior qualidade em termos ambientais, em parte proporcionadas pela Serra de Sintra (Horta, 2011). No entanto, este grupo de imigrantes tem, ao longo dos últimos anos, perdido uma importância relativa para outros grupos, nomeadamente para a comunidade brasileira, mas também para os PALOP e para os da Europa de Leste.

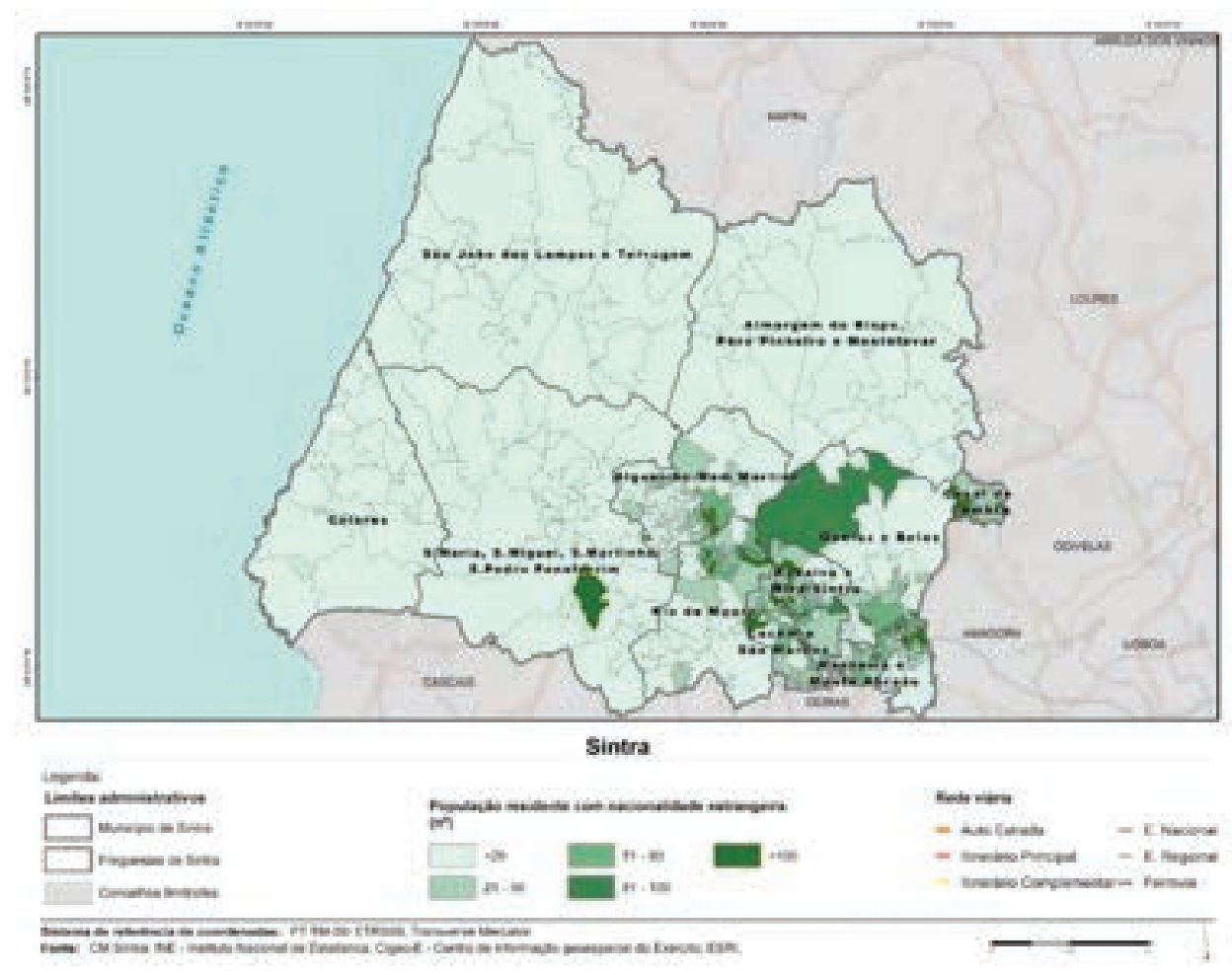

Fonte: INE, I.P., Censos 2011.

Figura 5. População residente com nacionalidade estrangeira, por secção estatística em 2011.

Refletindo sobre o perfil de habilitações desta população estrangeira, sobressaem os indivíduos provenientes dos continentes africano e asiático com piores habilitações, ao passo que os europeus e americanos apresentam um perfil de habilitações mais favorável. Deste modo, os asiáticos apresentam uma maior percentagem de população sem qualquer nível de escolaridade atingido (14,6\%, correspondendo a 113 indivíduos). Em termos absolutos ganham destaque os 1556 indivíduos africanos sem nenhum nível de escolaridade (Figura 6).

Com habilitações ao nível do ensino básico salientam-se os africanos, uma vez que 57,8\% apenas apresentam este nível de ensino (11099 indivíduos), sendo que 17,1\% (3277) apenas detém o $1^{\circ} \mathrm{CEB}, 12,8 \%$ o $2^{\circ} \mathrm{CEB}$ (2458) e $27,9 \%$ o $3^{\circ} \mathrm{CEB}$ (5364). 


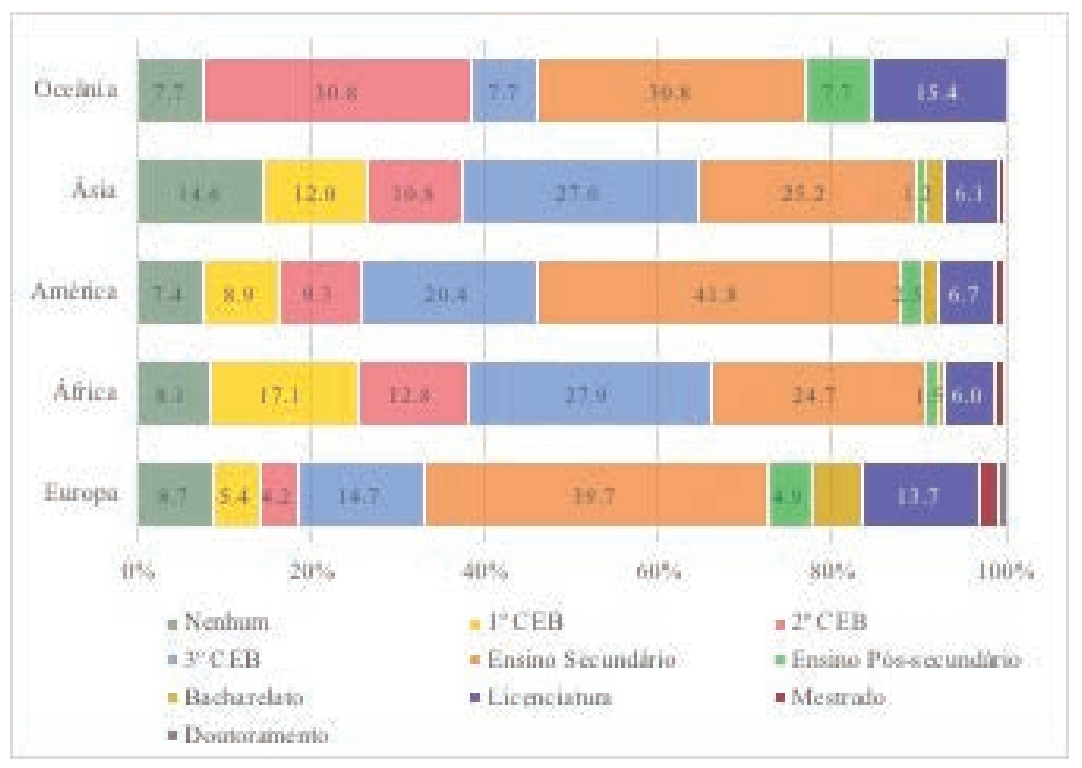

Fonte: INE, I.P., Censos 2011.

Figura 6. População estrangeira, por Continente de origem e nível de ensino mais elevado atingido, em 2011.

Tal como foi referido, os indivíduos com nacionalidade europeia e americana apresentam níveis de escolaridade superiores. Para esta afirmação, contribui a análise da população com o ensino secundário e com o ensino superior (licenciatura, mestrado e doutoramento). Deste modo, cerca de $41,8 \%$ e $39,7 \%$ dos residentes americanos e europeus, têm o ensino secundário como nível mais elevado atingido (3745 e 2394, respetivamente). Em termos comparativos, os provenientes dos continentes africano e asiático apresentam percentagens inferiores $(24,7 \%$ e $25,2 \%$, correspondendo a 4750 e 195 indivíduos). Por fim, cerca de $16,7 \%$ dos residentes provenientes de outros países europeus apresentam um nível de escolaridade superior (1006 indivíduos), seguindo-se os provenientes da Oceânia (15,4\%, correspondendo a 2 indivíduos) e do continente americano (7,9\%, correspondendo a 708 indivíduos).

Neste sentido, constata-se que os territórios do setor sudeste do território, com os seus mosaicos multiculturais e com o peso de uma população africana (e logo também de crianças e jovens afrodescendentes) que a população escolar se reflete nesses mesmo mosaicos (Figura 7). Com o quadro apresentado, em função das qualificações académicas, verifica-se que os alunos oriundos de um contexto social e cultural mais desfavorecido, e cujos pais (em particular a mãe) possuem um menor nível de habilitações escolares, são aqueles com maior propensão a um desempenho escolar abaixo do espectável (CNE, 2015; Cordeiro \& Alcoforado, $2015)^{3}$, algo que torna evidente o quadro de insucesso escolar observado nesse setor (Figura 8).

3 O sucesso escolar depende, em grande parte, do apoio direto e sistemático da família às crianças, compensando tanto dificuldades individuais como dificuldades escolares. Em famílias dotadas de recursos económicos e culturais, dentro dos quais se destacam o tempo livre e o nível de escolarização da mãe, expressos neste conceito de capital cultural, os resultados são superiores. A família que está por detrás do sucesso escolar, salvo exceções, ou conta com uma mãe em tempo integral ou uma "supermãe", como é 


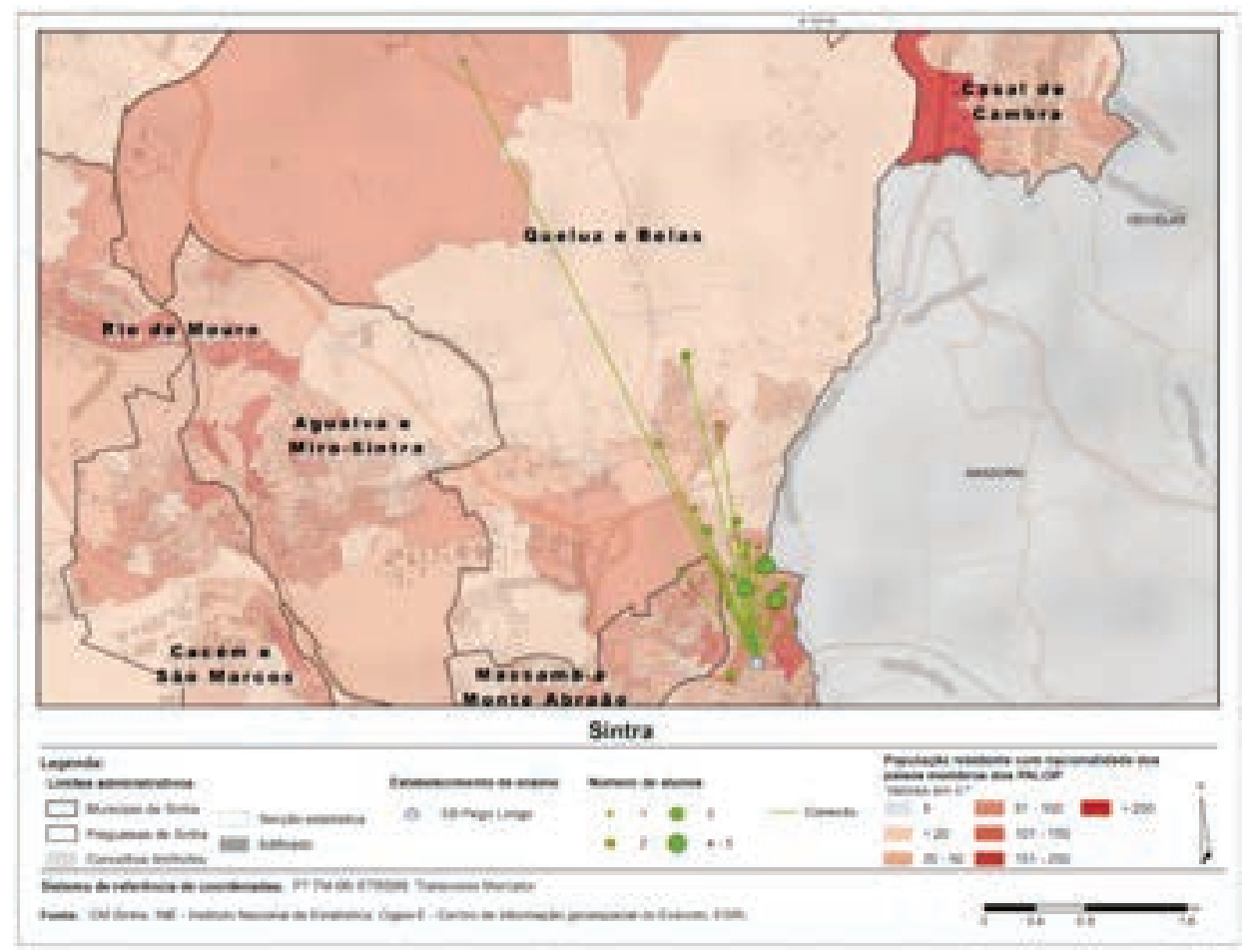

Figura 7. População estrangeira, com nacionalidade dos países PALOP, e número de alunos que frequentam a EB Pego Longo segundo a residência, no ano letivo de 2015/16.

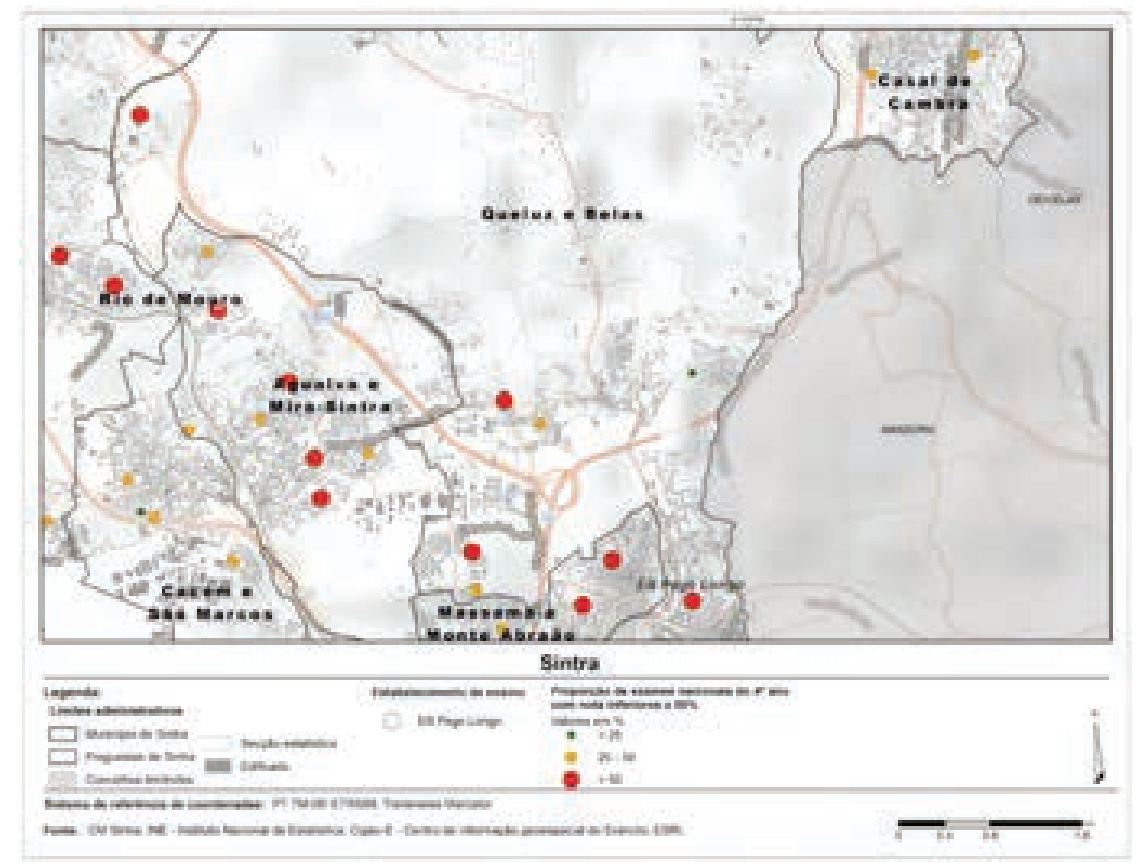

Figura 8. Proporção de exames nacionais do $4^{\circ}$ ano com nota inferior a $50 \%$ em escolas do setor sudeste de Sintra.

o caso daquelas que trabalham muitas horas e mesmo assim exercendo o papel de "professora" dos filhos em casa, ou contratando professores particulares para as chamadas explicações e até mesmo psicólogos e psicopedagogos, nos casos mais difíceis. 
É neste contexto que se entende o objetivo deste território municipal em definir estratégias para inverter a situação, trabalhando numa lógica de descriminação positiva, quer através de programas para melhoria do sucesso escolar e diminuição do abandono escolar, quer através de programas de inclusão social de imigrantes nas escolas e no território.

\subsection{Contextos multiculturais e Educação. Políticas locais de integração de imigrantes}

A multiculturalidade, constituindo-se como uma das características mais marcantes do município de Sintra e ao ser perspetivada como uma valiosa potencialidade deste território, tem vindo a assumir-se como o núcleo de diversos projetos orientados para a prevenção da exclusão e da discriminação nos diversos domínios (educativo, social, cultural, entre outros) e para a promoção da igualdade de oportunidades. Neste contexto, a dimensão do trabalho desenvolvido não só pelas escolas do município, mas também pela própria autarquia, revela-se essencial, demonstrando, desta forma, o reconhecimento da necessidade de reforço e de consolidação de mecanismos institucionais de inclusão, particularmente, a nível escolar.

Efetivamente, a diversidade cultural do concelho de Sintra, tendo inegáveis vantagens, uma vez que contribui para a multi/interculturalidade da sociedade e das escolas, para a partilha e coabitação de tradições culturais, de competências e de saberes, também acarreta uma complexidade social e uma miscigenação de culturas, trazendo por vezes problemas de comunicação, conflitos e mesmo novas formas de discriminação e de exclusão. Procurando maximizar as vantagens e anular os efeitos indesejáveis das desigualdades, já em 2015 Sintra apresentou o seu Plano Concelhio para a Integração dos Imigrantes $\left(\right.$ PCIIS $^{4}$ ), financiado pelo Fundo Europeu para a Integração de Nacionais de Países Terceiros (FEINPT), comprometendo-se a desenvolver uma estratégia global, na área da imigração, participada e integradora das ações, envolvendo diferentes entidades públicas, privadas e sem fins lucrativos, com base nas necessidades identificadas junto dos cidadãos, nacionais e estrangeiros, previstas para o horizonte temporal de 2015 a 2017.

Para além do conjunto de ações desenvolvidas no âmbito deste Plano, em concreto, é possível identificar um conjunto de outras iniciativas que têm vindo a ser implementadas no território, em diferentes áreas e escalas de atuação, mas que concertam a sua atuação com o objetivo predominante da promoção de uma melhor integração dos imigrantes, tanto ao nível da inclusão social, da promoção do sucesso ao longo dos diferentes ciclos e percursos escolares e da procura de uma progressiva melhoria da integração no mundo do trabalho. É esse o caso do Projeto Escolhas Sintra, destinado a crianças e jovens entre os 6 e os 30 anos, provenientes de contextos socioeconómicos mais vulneráveis, nomeadamente, descendentes

4 Os Planos Municipais para a Integração dos Imigrantes visam o aprofundamento das políticas locais, numa lógica de sustentabilidade e de governação integrada que conta com a participação de todos - entidades públicas e privadas - que em cada concelho trabalham em prol do acolhimento e integração dos imigrantes na sociedade portuguesa. 
de imigrantes, comunidades ciganas e emigrantes portugueses, com o objetivo e promover a inclusão social, tendo em vista a igualdade de oportunidades e o reforço da coesão social. É também o caso do Plano Municipal para a Igualdade, Cidadania e Promoção da Dignidade Humana (PMICPDH), destinado a profissionais de diferentes áreas e população em geral, incluindo população escolar, tendo como objetivo combater as desigualdades sociais e contribuir para uma sociedade mais inclusiva. Pode também referir-se o Plano para o acolhimento e integração dos refugiados no concelho de Sintra, com o objetivo de assegurar a capacidade de planeamento e de operacionalização do processo de acolhimento e integração de cidadãos refugiados. E pode, por fim, identificar-se o projeto IN AFRO Educação Inclusiva dos Afrodescendentes no Concelho de Sintra, tendo como público-alvo os alunos afrodescendentes do $1^{\circ} \mathrm{CEB}$ ao Ensino Secundário do Concelho de Sintra, com o objetivo de promover o envolvimento e o sucesso ao longo dos percursos escolares.

Ainda no que concerne às estratégias desenvolvidas pela autarquia e no âmbito da construção do Projeto Educativo Local, foi planeado como um dos seus eixos estratégicos, a dimensão "Escola Inclusiva e Sucesso Educativo", antevendo a estreita articulação entre os projetos já existentes, levados a cabo pelas escolas e pelo município, com uma nova ambição conjunta de pensar uma Escola para todos, durante mais tempo e que não descrimine. A referida dimensão abarca um conjunto de projetos e ações promotoras do sucesso educativo de todos os alunos do município de Sintra, pressupondo o envolvimento de todos os atores sociais com impacto na comunidade educativa, com vista à implementação de boas práticas e à corresponsabilização na promoção do sucesso escolar.

Assim, no âmbito do Programa de Ação do Pacto para o Desenvolvimento e Coesão Territorial da Área Metropolitana de Lisboa, o município de Sintra apresentou o Projeto "Planos Inovadores de Combate ao Insucesso Escolar no Concelho de Sintra" (Aviso no LISBOA-66-2016-22, do PORL 2014/2020), que prevê no domínio do eixo 7 - Investir na educação, na formação e na formação profissional para a aquisição de competências e na aprendizagem ao longo da vida -, e que preconiza como prioridade de investimento - a redução e prevenção do abandono escolar precoce e estabelecimento de condições de igualdade no acesso à educação infantil primária e secundário, incluindo percursos de aprendizagem formais, não formais e informais, para a reintegração no ensino e formação ${ }^{5}$.

Entre os diferentes domínios apresentados nesta candidatura destaca-se a ação "Inclusão", ancorada no princípio de que todos os alunos deverão desenvolver um conjunto de competências que lhes permitam exercer o seu direito de cidadania, através de uma educação de qualidade, tendo em linha de conta as suas especificidades, interesses e necessidades. A inclusão, enquanto forma de flexibilização da resposta educativa, constitui, na referida candidatura, um

5 O Programa Operacional Regional de Lisboa (PORL) 2014/2020 insere-se na estratégia Europa 2020, na qual estão definidos cinco grandes objetivos para a década 2010/2020, entre eles, reduzir as "taxas de abandono escolar para níveis abaixo dos 10\%" e "aumentar para, pelo menos, $40 \%$ a percentagem da população na faixa etária dos 30-40 anos que possui um diploma do ensino superior”. 
caminho para ultrapassar a problemática da exclusão, apresentando como principais objetivos a promoção da inclusão social e escolar de crianças e de jovens provenientes de contextos socioeconómicos vulneráveis, particularmente, dos imigrantes em risco de exclusão social dos imigrantes em risco de exclusão social e mais expostos a diferentes formas de insucesso escolar, através do desenvolvimento de competências de comunicação e/ou pessoais, de modo a combater a desigualdade de oportunidades educativas e a alcançar a equidade necessária para que a igualdade de acesso corresponda à possibilidade real de sucesso.

Tendo em consideração a existência de alunos de várias nacionalidades nos estabelecimentos de ensino do município, apresentando muitos deles evidentes dificuldades ao nível da língua portuguesa, facto que compromete à partida os seus percursos escolares, a ação "Inclusão" pretende reforçar o domínio da língua portuguesa, aprofundando, ao mesmo tempo, estratégias de aprendizagem potenciadoras da diferenciação pedagógica e do trabalho autónomo, visando uma verdadeira igualdade de oportunidades e de sucesso educativo.

De salientar que o Projeto "Planos Inovadores de Combate ao Insucesso Escolar no Concelho de Sintra" integra outras ações que, necessariamente, se relacionam com a ação "Inclusão", designadamente, no que diz respeito ao desenvolvimento de competências pessoais e sociais dos alunos e à necessidade de capacitação e de envolvimento parental, já que a família é encarada como um importante agente socializar e influenciador de atitudes e comportamentos face à escola. Importa mencionar que esta candidatura privilegia não só a capacitação dos profissionais das escolas para a aquisição de ferramentas e estratégias que lhes possibilitem uma ação eficaz e adequada com todos os alunos, independentemente da sua origem, mas também, o estabelecimento de parcerias com entidades locais com vista ao efetivo trabalho em rede ao nível da inclusão.

Como resposta a um território multicultural e diverso como o de Sintra, inevitavelmente, as escolas ao longo do tempo têm vindo a traçar caminhos no âmbito da promoção da inclusão e da igualdade de oportunidades, alcançando maior expressividade os seis Territórios Educativos de Intervenção Prioritária (TEIP) ${ }^{6}$ existentes no município. De facto, estamos perante uma realidade complexa, cuja comunidade educativa revela características socioeconómicas distintas, salientando-se um número muito significativo de imigrantes e, consequentemente, uma grande diversidade linguística, étnica e cultural, na qual se observa um elevado número de famílias com baixos níveis de qualificação, marcadas por situações de desemprego/empregos precários, facto que gera problemas acrescidos ao nível do acompanhamento escolar dos seus educandos.

6 O Programa TEIP constitui uma iniciativa governamental, implementada atualmente em diversos agrupamentos de escolas/escolas não agrupadas que se localizam em territórios económica e socialmente desfavorecidos, marcados pela pobreza e exclusão social, onde a violência, a indisciplina, o abandono e o insucesso escolar mais se manifestam. O programa apresenta como principais objetivos a prevenção e redução do abandono escolar precoce e do absentismo, a diminuição da indisciplina e a promoção do sucesso educativo de todos os alunos. 
As estratégias a desenvolver no âmbito da inclusão, propostas pelos agrupamentos de escolas, dividem-se em duas grandes vertentes. A primeira encontra-se centrada na promoção de atividades culturais, recreativas e outras que criem um maior envolvimento da comunidade cigana com a escola, apostando na capacitação dos docentes e não docentes ao nível da cultura cigana e da concretização de estratégias de intervenção articuladas e direcionadas para esta comunidade. Já a segunda vertente surge mais orientada para a integração plena no meio escolar dos alunos oriundos de países estrangeiros, cuja línguamaterna não é o português, promovendo atividades de aquisição e de progressão no domínio da língua portuguesa. A título de exemplo, refere-se o projeto "Turma de Acolhimento" que pretende proporcionar aos alunos provenientes do estrangeiro, que vão chegando às escolas, ao longo do ano e sem domínio da língua portuguesa, uma integração mais rápida e facilitadora do seu sucesso escolar, possibilitando a aquisição das competências linguísticas de forma acelerada e, progressivamente, uma plena integração nas turmas curriculares.

Ainda no quadro da elaboração do Projeto Educativo Local, desenvolvido, através de uma metodologia muito participada e que se encontra em fase de discussão pública para posterior aprovação pelos órgãos autárquicos, está prevista a implementação de um conjunto de ações tendentes a consolidar um eixo estratégico, designado de Interculturalidade, Migrações e Coesão Social, pensado para aglomerar o desenvolvimento articulado de políticas educativas, sociais e culturais, com o objetivo de evitar a exclusão e a discriminação nos domínios social, económico, cultural, religioso, educativo e linguístico e para integrar a diversidade cultural, o diálogo intercultural e promover a igualdade de oportunidades entre os diferentes setores da sociedade.

\section{Síntese conclusiva e desafios para um território de encontros interculturais}

Ainda no final do século passado, no âmbito das reflexões alargadas que corporizaram o Relatório "Educação um Tesouro a Descobrir” Delors (1996), deu-se clara expressão à necessidade de assumir a diversidade e a multipertença como uma riqueza, reafirmando a UNESCO (2001), já no início deste século, através da Declaração Universal sobre a Diversidade Cultural que "a diversidade cultural é uma das fontes de desenvolvimento, entendido não só como crescimento económico, mas, também, como meio de acesso a uma existência intelectual, afetiva, moral e espiritual satisfatória".

Por seu lado, a Comissão Europeia, em articulação com os estados membros, tem vindo a promover iniciativas ao nível legislativo e dos sistemas e políticas educativas, tendo em vista a formação dos agentes educativos, particularmente professores, para lidarem com a complexidade e a interculturalidade no ensino, a aprendizagem da pedagogia intercultural, o reconhecimento da diversidade nas relações internacionais e globais e a solidificação de uma identidade europeia, para além, da diversidade nacional (Eurydice, 2004), acreditando que esta nova Europa, culturalmente ainda mais diversa, pode constituir-se, através de 
políticas educativas, sociais, económicas e culturais adequadas, como um desafio real de incremento contínuo de progresso e bem-estar comum.

Neste contexto, compete aos Estados e aos órgãos de poder local a criação e desenvolvimento de iniciativas nacionais, mas também com caraterísticas de bottom up, com o objetivo de evitar a exclusão e a discriminação nos domínios social, económico, cultural, religioso, educativo e linguístico e, principalmente, para integrar a diversidade cultural, e promover o diálogo intercultural, visando a igualdade de direitos, deveres e oportunidades nos diferentes setores da sociedade.

Através do conjunto articulado de iniciativas enunciadas, o município de Sintra tem procurado criar e implementar políticas de acolhimento e integração, assumindo-se como um território marcadamente multicultural e diverso, que deseja, igualmente, ser integrador e inclusivo. É então possível registar uma evolução significativa, em termos quantitativos, nas políticas de acolhimento e integração, também porque os responsáveis autárquicos acreditam que a heterogeneidade individual e comunitária e a possibilidade de reunir a experiência da pluralidade de mundos diferentes, numa sociedade municipal progressivamente mais diferenciada, se pode traduzir, envolvendo todos, num horizonte temporal mais alargado, na melhor oportunidade para construir um concelho melhor, ao nível cultural, social e económico.

O recente processo de elaboração, participada, do Projeto Educativo Local procura dar mais um passo, acrescentando ambição quantitativa e qualitativa às iniciativas que visam incrementar o diálogo intercultural (Lahire, 2011) como ação política, a nível municipal. O primeiro grande desafio passará por entender o Projeto Estratégico de Desenvolvimento do município e o Projeto Educativo Local como interdependentes e mutuamente desafiantes. Se constitui uma opção estratégica construir um espaço territorial inteligente e inclusivo, numa lógica de desenvolvimento integrado e sustentável, onde o diálogo, ou o encontro intercultural, seja um dos seus principais princípios organizadores, será forçoso planear, desenvolver e avaliar as iniciativas educativas capazes de (trans)formar as pessoas e as comunidades para essas mudanças desejáveis, assim como será obrigatório enriquecer as atividades educativas com a dinâmica das aprendizagens resultantes dos encontros interculturais.

Para que isto seja possível, o Projeto Educativo Local deve entender o diálogo intercultural como ação política e educativa, transversal a todos os seus eixos de desenvolvimento, atravessando a vida e os espaços de vida de todas as pessoas, cuidando, em particular, de associar respostas educativas com participação cidadã e económica. Sendo indiscutível que as mudanças significativas apenas acontecem em resultado de uma associação virtuosa de mobilização de recursos num espaço e tempo de transformação, conjugando projetos e vontades, uma Europa intercultural e socialmente coesa apenas poderá ser ambicionada, conjuntamente com projetos nacionais e transnacionais, a partir de diálogos e encontros locais favorecidos por políticas promotoras de um multicultaralismo interativo. 


\section{Referências bibliográficas}

BAGANHA, Maria - Insercion de los inmigrantes en la economía informal: el caso português. Actas del Congresso Internacional de la Población, V Congresso de ADEH. España: Instituto de Estudios Riojanos. ISBN 84-89362-61-0. Vol. II (1999) p. 47-76.

BAGANHA, Maria \& GÓIS, Pedro - Migrações internacionais de e para Portugal: o que sabemos e para onde vamos? Revista Crítica de Ciências Sociais. Coimbra: Centro de Estudos Sociais. ISSN 2182-7435. No 52/53 (1998) p. 229-280.

BRAH, A. - Cartographies of diaspora. Contesting identities. London: Routledge, 1996. 280 p. ISBN-10: 0415121264.

BOUSSEMART, Jean-Michel; GODET, Michel - Europe 2050: Demographic Suicide and Low Growth on the Old Continent. European issues. Fondation Robert Schuman. $\mathrm{N}^{\circ}$ 462 (2018).

CASTRO, Fátima - A Europa do Outro - A imigração em Portugal no início do século xxi. Estudo do caso dos imigrantes da Europa de Leste no concelho de Vila Viçosa. Lisboa: Alto-Comissariado para a Imigração e diálogo intercultural (ACIDI), 2008. 263 p. ISBN 978-989-8000-50-7.

CORDEIRO, A. M. R.; ALCOFORADO, L. (cord.) - Programa intermunicipal de prevenção do abandono escolar e promoção da igualdade de acesso ao ensino da comunidade intermunicipal região de Coimbra - Contextos territoriais preditores do (in) sucesso escolar - Documento síntese e plano de ação. Coimbra: Faculdade de Letras da Universidade de Coimbra, 2015. 176 p, (Relatório Técnico).

DELORS, J. et al. - Educação: um tesouro a descobrir. Relatório para a UNESCO. Comunicação Internacional sobre a Educação para o Século XXI. Porto: Editora ASA, 1996. 288 p. ISBN: 85-249-0673-1.

FERREIRA, E.; RATO, H.; GEADA, F.; RODRIGUES, S. - Economia e Imigrantes: contribuição dos imigrantes para a economia portuguesa. Oeiras: Celta Editora, 2000. 99 p. ISBN 972-774-071-5.

FONSECA, Maria - Portugal no sistema das migrações internacionais na Europa: tendências recentes e perspectivas futuras. In CAVACO, Carminda (coord.) - Actas do seminário internacional Repensar Portugal na Europa. Perspectivas de um País Periférico. Lisboa: Estudos para o Planeamento Regional e Urbano, 2002. ISBN 9726361354. 393 p.

GIROUX, Henry - Theories of reproduction and resistance in the new sociology of education: a critical analysis. Harvard Educacional Review. USA: Harvard University. ISSN 0017-8055. Vol. 53, N³ (1983) p. 257-293.

GÓMEZ, Emilio - Pueblos y lenguas de Europa, Asia, África y Oceanía. Navarra: Ulzama Digital, 2011. 421 p. ISBN 9788479560836.

GRANOVETTER, M. - The strength of weak ties. American Journal of Sociology. USA: University of Chicago Press. ISSN 15375390, 00029602. Vol. 78 No 6 (1973) p. 1930 -1938. 
HAESBAERT, Rogério - $O$ mito da desterritorialização. Rio de Janeiro: Bertrand Brasil, 2004. 395 p. ISBN 9788528610611.

HEMMASI, M.; DOWNES, M. - Cultural distance and expatriate adjustment revisited. Journal of Global Mobility: The Home of Expatriate Management Research. United Kingdom: Emerald Publishing. ISSN: 2049-8799. Nº 1 (1) (2013) p. 72 -91.

HORTA, Ana (coord.) - Diagnóstico da População Imigrante no Concelho de Sintra - Desafios e Potencialidades para o Desenvolvimento Local. Lisboa: Coleção Portugal Imigrante, ACIDI - Alto Comissariado para a Imigração e Diálogo Intercultural, 2011. 242 p. ISBN 978-989-685-037-1.

HUNTINGTON, Samuel - The Clash of Civilizations?. Foreign Affairs. New York: JSTOR. ISSN 0015-7120. Vol. 72, No. 3 (1993) p. 22 -49.

HUNTINGTON, Samuel - O Choque das civilizações e a mudança na ordem mundial. Lisboa: Gradiva, 1999. 420 p. ISBN 978-972-662-652-7.

LAHIRE, Bernard - Individus, (inter)cultures et politique. Education Permanente. France. ISSN: 0339-7513. No 186 (2011) p. 21-32.

MACHADO, Paulo - Multiculturalidade e Estados multinacionais na Europa. Revista Janus [ Em linha] ( 2005). [Consult. 20 de fevereiro de 2018]. Disponível em https://www. janusonline.pt/arquivo/2005/2005.html ISSN 1647-7251.

MAALOUF, Amin - Identidades assassinas. Lisboa: Difel, 1999. 176 p. ISBN 9789722909570.

MALHEIROS, Jorge - Imigrantes na região de Lisboa. Os anos de mudança. Lisboa: Edições Colibri, 1996. 238 p. ISBN 9789728288358.

MALHEIROS, Jorge - Minorias étnicas e segregação nas cidades. Uma aproximação ao caso de Lisboa, no contexto da Europa Mediterrânica. Finisterra, Lisboa. ISSN 04305027. Vol. XXXIII, Nº 66 (1998). p. 91-118.

PEIXOTO, J.; CRAVEIRO, D.; MALHEIROS, J.; OLIVEIRA, I. - Migrações e sustentabilidade demográfica: Perspetivas de evolução da sociedade e economia portuguesas. Lisboa: Fundação Francisco Manuel dos Santos, 2017. 292 p. ISBN 978-989-8863-17-1.

PIRES, Rui - Migrações e Integração. Teoria e aplicações à sociedade portuguesa. Oeiras: Celta editora, 2003. 289 p. ISBN 9727741851.

RAMOS, Natália - Educar para a interculturalidade e cidadania: princípios e desafios. In L. ALCOFORADO, L. et al - Educação e Formação de Adultos. Políticas, Práticas e Investigação. Coimbra: Ed. da Universidade de Coimbra, 2011. ISBN 978-989-26-0136-6. p. 189-200.

RAMOS, Natália - Sociedades multiculturais, interculturalidade e educação: desafios pedagógicos, comunicacionais e políticos. Revista Portuguesa de Pedagogia. Coimbra: Faculdade de Psicologia e Ciências da Educação da Universidade de Coimbra. ISSN 0870-418X. No 41-3 (2007). p. 223-244. 
ROSA, M.; SEABRA, H.; SANTOS, T. - Contributos dos "imigrantes" na demografia portuguesa. O papel das populações de nacionalidade estrangeira. Lisboa: Alto Comissariado para a Imigração (ACIME), 2003. 136 p. ISBN 972-98959-5-3.

SEABRA, T.; MATEUS, S.; RODRIGUES, E.; NICO, M. - Trajetos e projetos de jovens descendentes de imigrantes à saída da escolaridade básica. Lisboa: Observatório da Imigração, 2011. 190 p. ISBN 978-989-685-014-2.

SEF - Relatório de Imigração, Fronteiras e Asilo. Lisboa: Serviço de Estrangeiros e Fronteiras, 2016. 84 p.

SEN, Amartya - Identidade e Violência. Lisboa: Tinta-da-China, 2007. 254 p. ISBN: 9789728955199.

TOURAINE, Alain - Poderemos viver juntos? Iguais e Diferentes. Brasil: Vozes, 1999. 420 p. ISBN 9789727710638.

TOURRAINE, Alain - Un nouveau paradigme pour comprendre le monde d'aujourd'hui. Paris: Fayard, 2005. 363 p. ISBN-13: 978-2213623634.

UNESCO - Open File on Inclusive Education. Paris: Unesco, 2001. 146 p.

Artigo Recebido a 28 de março de 2018 | Aceite a 03 de abril de 2018 